\title{
A new genus and species of Homoiopteridae from the Upper Carboniferous of the Intra-Sudetic Basin, Czech Republic (Insecta: Palaeodictyoptera)
}

\author{
JAKUB PROKOP ${ }^{1}$ and ANDRÉ NEL ${ }^{2}$ \\ ${ }^{1}$ Department of Zoology, Charles University, Viničná 7, CZ-128 44, Praha 2, Czech Republic; e-mail: jprokop@natur.cuni.cz \\ ${ }^{2}$ CNRS UMR 5143, Muséum National d'Histoire Naturelle, Entomologie, 45 rue Buffon, F-75005 Paris, France; e-mail: \\ anel@mnhn.cz
}

Key words. Insecta, Dictyoneuridea, Palaeodictyoptera, Homoiopteridae, gen. n., sp. n., taxonomy, Palaeozoic, Upper

Carboniferous, Duckmantian, Intra-Sudetic Basin, Czech Republic

\begin{abstract}
New palaeodictyopterid Paraostrava stanislavi gen. n., sp. n. is described from the Upper Carboniferous (Duckmantian) deposits of the Jan Šverma Mine in northern Bohemia (Czech Republic). The new taxon based on hindwing venation is attributed to Homoiopteridae and compared with the other homoiopterid and heolid genera within Homoiopteroidea. Due to the poor state preservation of Boltopruvostia robusta, we consider this taxon as Palaeodictyoptera: Homoiopteridae of uncertain position and restore the well defined genus Ostrava Kukalová, 1960 (type species Ostrava nigra Kukalová, 1960). Some uncertainties in the current state of knowledge on the taxonomy and phylogeny of the Homoiopteridae are pointed out. The characters matrix used to separate the genera of Homoiopteroidea is included.
\end{abstract}

\section{INTRODUCTION}

The fossil insect order Palaeodictyoptera Goldberg, 1854 within superorder Dictyoneuridea Handlirsch, 1906 (Palaeodictyopteroida sensu Bechly, 1996) represents a widely diverse group of Palaeozoic insects ranging from the Lower Carboniferous (Namurian A) through Permian up to the Lower Triassic (Middle "Buntsandstein" by single record of Thuringopteryx gimmi Kuhn, 1937) with a peak of abundance in the Upper Carboniferous (Bechly, 1997; Sinitshenkova, 2002). Palaeodictyopteran insects with a distribution mainly restricted to the tropical belt of the northern hemisphere are commonly found in Euroamerican Upper Palaeozoic deposits, which indicate their probable thermophily (Sinitshenkova, 2002). The taxon Palaeodictyoptera is considered to be paraphyletic after Bechly (1996). Because of this state, it is necessary to revise the described species in the perspective of a future phylogenetic study of this group. But many species are based only on more or less complete wings. Thus, such analysis may be very difficult to achieve. Further orders of Palaeodictyopteroida like Megasecoptera, Diaphanopterodea and Permothemistida differ clearly in wing venation patterns and are therefore likely to be monophyletic groups (Grimaldi, 2001). We follow the wing venation terminology of Kukalová-Peck (1991). The systematics of Palaeodictyoptera is mainly based on the work of Sinitshenkova (2002), partly adapted from Riek (1976). Both systems are critically reviewed and discussed on the current position of Homoiopteridae.

The Intra-Sudetic Basin is a NW-SE extending structure situated in the northern part of former Bohemia (Czech Republic) (see Fig. 1). The major part of this basin lies in the territory of Poland while a narrow prominence is located in Žaclér surroundings and Broumov in the Czech Republic. The basin is filled with Lower Car- boniferous to Triassic continental sediments (Spudil, 1999). Generally, the overlying deposits of Šverma mine group seams are of fluvial origin. Zoopalaeontological and phytopalaeontological records were reviewed by Tásler et al. (1979).

\section{TAXONOMIC PART}

\section{Family Homoiopteridae Handlirsch, 1906}

List of genera after Carpenter (1992) supplemented by Brauckmann \& Becker (1992)*:

Adolarryia Kukalová-Peck \& Richardson, 1983; Ametretus Handlirsch, 1911*; Amousus Handlirsch, 1911*; Boltopruvostia Strand, 1929; Homoioptera Brongniart, 1893; Larryia Kukalová-Peck \& Richardson, 1983; Mammia Handlirsch, 1906*; Mazonopterum KukalováPeck \& Richardson, 1983; Mazothairos Kukalová-Peck \& Richardson, 1983; Parathesoneura Sinitshenkova, 1977; Scepasma Handlirsch, 1911*; Thesoneura Carpenter, 1944; Turneropterum Kukalová-Peck \& Richardson, 1983.

\section{Genus Paraostrava gen. n.}

Type species. Paraostrava stanislavi sp. n. by present description.

Diagnosis. Homoiopterid genus; based on hind wing venation; Paraostrava gen. n. differs from all other homoiopterid genera by combination of the following characters: RA and RP diverging distally of division $\mathrm{M}$ into MA and MP; basal part of RP not very long; area between RP and RA with numerous long sigmoidal veinlets, twice as wide as that between RP and MA; MA simple; MP with seven branches; $\mathrm{CuA}$ with two weak branches; $\mathrm{CuP}$ with two branches; reticulate venation (socalled "archedictyon") reduced but still present through numerous irregular cells. 


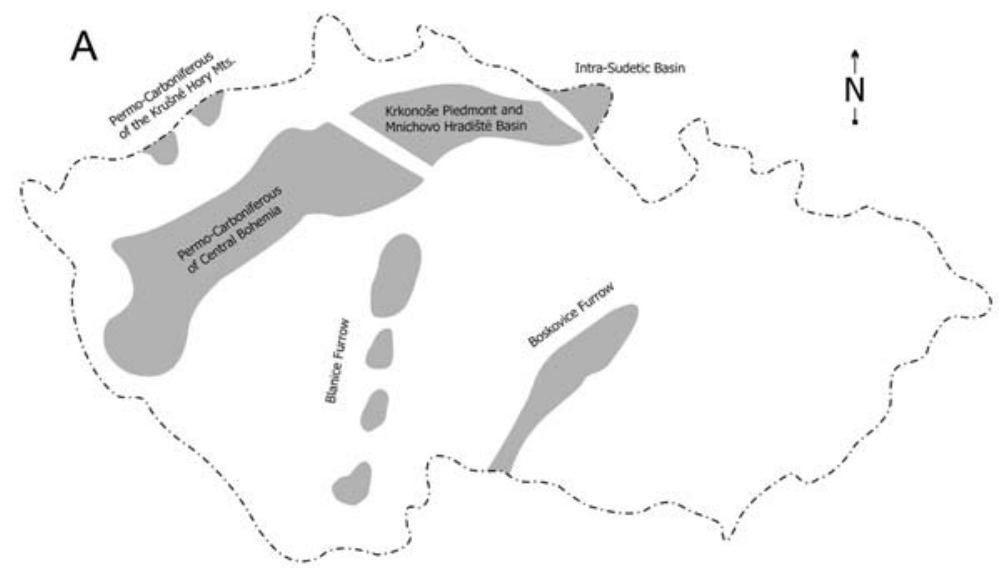

Fig. 1. A - Geographical map of Permo-Carboniferous limnic basins of the Bohemian Massif and position of the Intra-Sudetic Basin. B - Stratigraphic column of the Intra-Sudetic Basin division with proximate time level of the presented fossil (gray box). Abbreviations: EL - Early Langsettian, LL - Late Langsettian, ED - Early Duckmantian, LD - Late Duckmantian.

Etymology. Para - meaning similar to the genus Ostrava; feminine in gender.

\section{Paraostrava stanislavi sp. $\mathbf{n}$.}

(Figs 2-3)

Description. Wing membrane probably hyaline; wing covered with a dense irregular network, except in the more poorly preserved regions, i.e. the basal parts of areas between $\mathrm{ScP}$ and $\mathrm{R}, \mathrm{R}$ and $\mathrm{M}$, and $\mathrm{MA}$ and $\mathrm{MP}$; extreme apex of convex $\mathrm{ScA}$ visible at its point of fusion with anterior wing margin, $87.9 \mathrm{~mm}$ from wing apex; concave ScP straight, reaching anterior wing margin very distally, $20.4 \mathrm{~mm}$ close to wing apex; numerous small simple cross-veins in area between $\mathrm{C}$ and ScP; basal part of area between $\mathrm{ScP}$ and $\mathrm{R}$ poorly preserved but with some visible cross-veins, distal part of same area with several short cross-veins; RA simple and straight, ending on anterior margin $8.6 \mathrm{~mm}$ from wing apex; RA and RP area with numerous long sigmoidal cross-veins; base of $\mathrm{RP} 48.4 \mathrm{~mm}$ from wing apex, $25.7 \mathrm{~mm}$ distal to division fork: $\mathrm{M}$ divides into MA and MP; first fork of RP 12.9 $\mathrm{mm}$ distal to its base, both two basal forks of RP divided into three branches; RP reaching wing apex; MA simple, slightly curved, ending on posterior wing margin 17.8 mm from wing apex; MP divided dichotomously into seven branches; MP area very broad reaching the posterior wing margin from 20.4 to $47.3 \mathrm{~mm}$ of wing apex; a rather strong oblique cross-vein between $M$ and $R$, emerging from $M$ at the point of division of $M$ into MA and MP; at the same point, another strong oblique crossvein between $\mathrm{CuA}$ and $\mathrm{M}$; $\mathrm{CuA}$ slightly curved, with two short but strong branches ending on posterior wing margin; fork of $\mathrm{Cu}$ into $\mathrm{CuA}$ and $\mathrm{CuP}$ poorly preserved, probably $95 \mathrm{~mm}$ from wing apex; CuP slightly curved, more or less parallel to $\mathrm{CuA}$ and forked into two branches, first $51.4 \mathrm{~mm}$ and second $55.0 \mathrm{~mm}$ from posterior wing margin; five anal veins preserved, forming a large anal area (hind wing).
$\mathrm{B}$

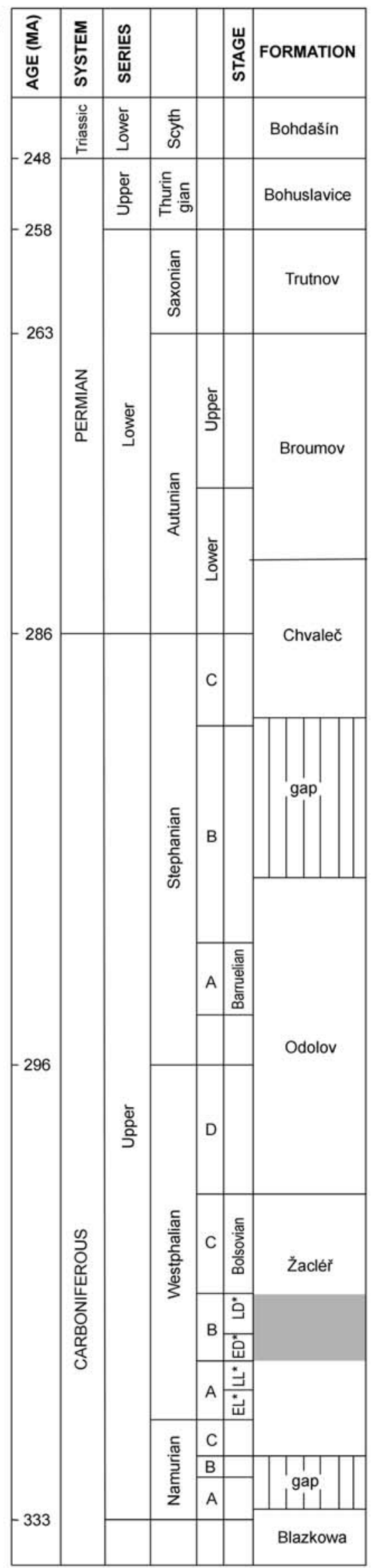



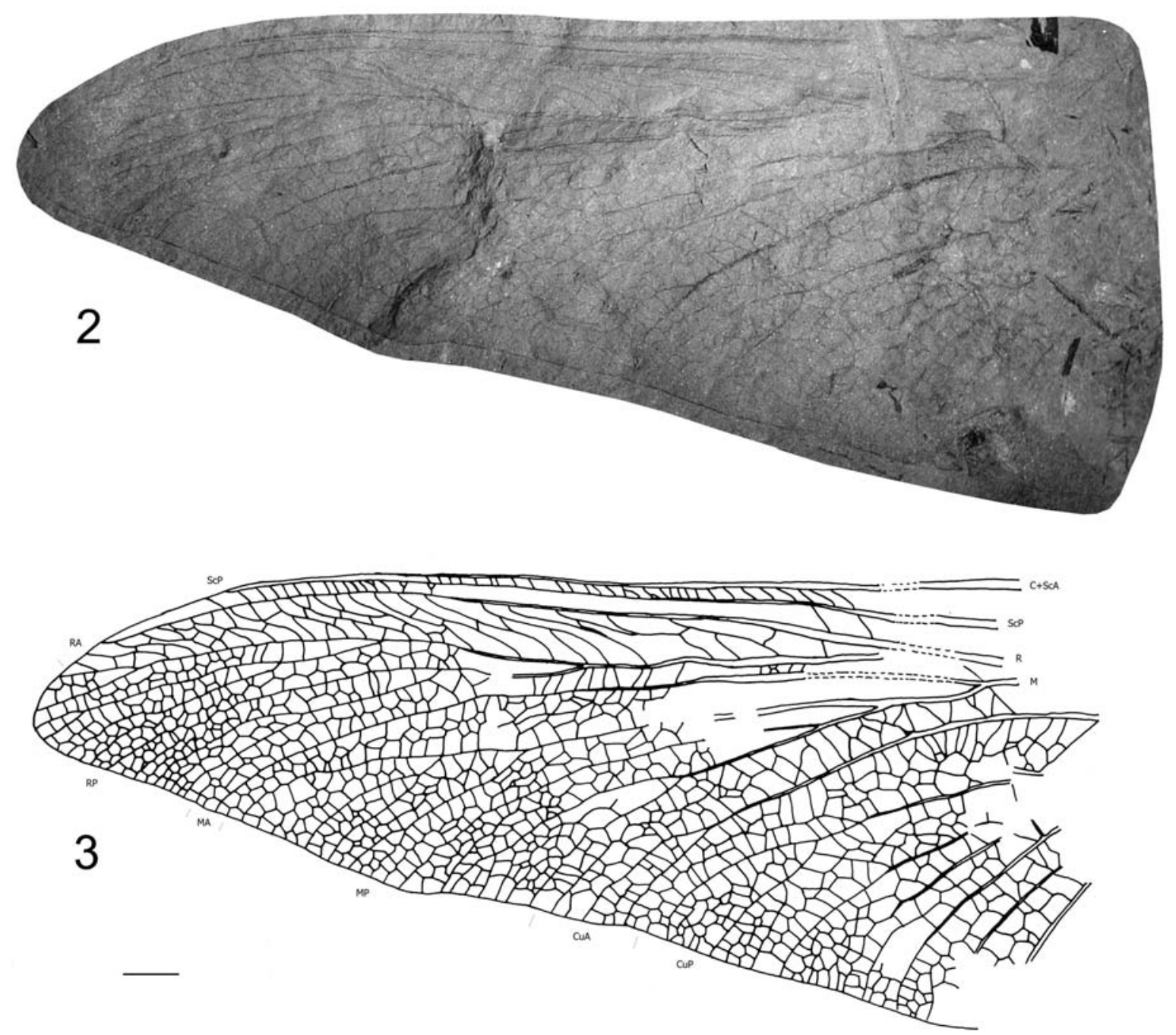

Figs 2-3: Paraostrava stanislavi gen. n. et sp. n. 2 - Holotype specimen No. NM-Me128; 3 - hind wing venation. Scale $=5 \mathrm{~mm}$.

Dimensions. Length of fragment about $95 \mathrm{~mm}$, probable total length about $125 \mathrm{~mm}$ (wingspan more than $250 \mathrm{~mm}$ ); width of fragment about $40 \mathrm{~mm}$.

Holotype. Specimen NM-Me128 the distal two-thirds of a well-preserved hind wing, secondary coloured in red by ironoxide, National Museum, Prague, Czech Republic

Type locality. Jan Šverma (formerly Julia) Mine in Žacléř (Schatzlar in German literature), Intra-Sudetic Basin, Czech Republic.

Type strata. Upper Carboniferous, Duckmantian (formerly Westphalian B), Žacléř Formation.

Etymology. Patronymic; named after Stanislav Opluštil, donator of this fossil.

Discussion. The current state of our knowledge on higher systematics and division of Palaeodictyopteroida sensu Bechly (1996) is rather complicated and partly confusing. There is no real phylogenetic analysis of this group that we can simply follow. In this case we trace both currently supported systems with additional comments.

First, it is not possible to follow the key of the "Eupalaeodictyoptera" proposed by Riek (1976: 230). For example, this author characterized Homoiopteroidea sensu Riek (1976) by the following characters: "CuA branched"; "MA simple"; "ScP extending almost to wing apex". But the CuA is simple in several taxa currently included in the Homoiopteridae (Scepasma gigas Handlirsch, 1911, and Mazonopterum wolfforum Kukalová-Peck \& Richardson, 1983) (Kukalová-Peck \& Richardson, 1983).

Sinitshenkova (2002: Fig. 138) proposed a new phylogeny and system of the superorder Dictyoneurida Handlirsch, 1906 (Palaeodictyopteroida sensu Bechly, 1996). This system is not based on a strict use of the cladistic method. At least in the most basal dichotomy, the clade Dictyoneurina is supported by the alleged synapomorphy "wing wide basally" and its sister clade Frankenholziina is supported by the alleged opposite state of character "wing base narrow", also considered as a synapomorphy. The indication of an outgroup to polarize the characters would be suitable. Thus, Sinitshenkova's classification cannot be considered based on the cladistic method, even if it uses the cladistic terminology.

Nevertheless, we shall provisionally follow Sinitshenkova's classification in this paper. We tentatively include 
Paraostrava stanislavi gen. n., sp. n. in the group (Homoiopteroidea + Spilapteroidea) because of the following characters: "wing wide basally"; "wing with enriched venation"; "wing not long and narrow, especially in its apical half"; "ScP extending well beyond wing midlength". Sinitshenkova (2002) added the "CuA branching" to characterize this group, but some Homoiopteridae have a $\mathrm{CuA}$ simple, as indicated above. She separated the Homoiopteroidea from the Spilapteroidea after the "archedictyon" lost, veins polymerized' for the former group. But the "archedictyon" of some Spilapteridae (Spilaptera, see Carpenter, 1992: Fig. 25.4) is less developed than that of some Homoiopteridae (Homoioptera, see Kukalová-Peck \& Richardson, 1983: Fig. 19). Thus, this character is difficult to follow. But Riek (1976) proposed a different character to separate the Homoiopteroidea from the Spilapteroidea, i.e. MA simple in the former group and branched in the latter.

Sinitshenkova (2002: 117) indicated that the Homoiopteroidea and the Spilapteroidea differ from Eugereonoidea in multibranched MA. But the Homoiopteridae have MA simple or with very short and weak distal branches (see Kukalová-Peck \& Richardson, 1983).

Sinitshenkova (2002: 117) divided the Spilapteroidea into Spilapteridae Handlirsch, 1906, Fouqueidae Handlirsch, 1906, Homothetidae Scudder, 1865, Lamproptilidae Handlirsch, 1906, Mecynostomatidae Kukalová, 1969, and Aenigmatidiidae Rohdendorf, 1961. All these groups have MA with long branches. Note that the type genus of the Aenigmatidiidae, Aenigmatidia Rohdendorf, 1961 (type species Aenigmatidia kaltanica Rohdendorf, 1961) has no "archedictyon" (see Rohdendorf, 1961: Fig. 34), unlike what Sinitshenkova (2002) indicated for the Spilapteroidea in her classification of the "Dictyoneurida". The same author subdivided the Homoiopteroidea into Homoiopteridae Handlirsch, 1906 and Heolidae Handlirsch, 1906. Both have a MA simple (for Heolidae see Handlirsch, 1906a: P1. 11, Fig. 6, 1906b: 678, Fig. 5). We attribute Paraostrava into this superfamily sensu Sinitshenkova (2002).

First, Paraostrava differs from the Miracopteron Novokshonov, 1993 (Miracopteridae Novokshonov, 1993 of order uncertain but with "similarities" with the Homoiopteridae, Miracopteron mirabile Novokshonov, 1993, based on the base of a hind wing) at least in its position of the $\mathrm{M}$ fork clearly distal in Paraostrava (Novokshonov, 1993).

Within the Homoiopteroidea, Homoioptera gigantea Agnus, 1902, Homoioptera vorhallensis Brauckmann \& Koch, 1982, Homioptera woodwardi Brongniart, 1893, Homoioptera kortumi Brauckmann \& Herd, 2002, Thesoneura americana Carpenter, 1944, and Heolus providentiae Handlirsch, 1919 (Heolidae), have the area between RA and RP without numerous long sigmoidal secondary veins (only few in Homoioptera), the fork of $\mathrm{M}$ into MA and MP distal to the level of the base of RP, and a CuA with 3-4 branches, unlike Paraostrava (Kukalová, 1969; Brauckmann \& Koch, 1982; Kukalová-Peck \& Richardson, 1983; Brauckmann \& Herd, 2002).
Homoioptera latipennis (Handlirsch, 1904) differs from Paraostrava in having the area between RA and RP as broad as that between RP and MA (Handlirsch, 1904: Figs 4-5).

Adolarryia bairdi Kukalová-Peck \& Richardson, 1983 is based on a nymph, difficult to compare with an adult wing. Nevertheless, it has a $\mathrm{CuA}$ divided into long branches, unlike Paraostrava. Monsteropterum moravicum Kukalová-Peck, J. 1972 was attributed to Palaeodictyoptera with an uncertain systematic position by Carpenter (1992) and then relocated within Megasecoptera after the presence of the tergal projections by KukalováPeck (pers. comm.). It is based on a body with wing bases that cannot be compared with Paraostrava. Further three taxa were also considered by Carpenter (1992) as Palaeodictyoptera with uncertain position, although Brauckmann (1991a) listed them in Homoiopteridae (see also Brauckmann \& Becker, 1992: 139). Amousus mazonus Handlirsch, 1911 and Ametretus laevis Handlirsch, 1911 are both based on hind wing bases, with forked $\mathrm{CuA}$, unlike Paraostrava. Mammia alutacea Handlirsch, 1906 is based on a very incomplete wing fragment, but differing from Paraostrava in its MA strongly curved basally.

Mazothairos enormis Kukalová-Peck \& Richardson, 1983 is based on the tergum of a single segment of a thorax. Of course, it is not possible to compare it with the other species of the family. Turneropterum turneri Kukalová-Peck \& Richardson, 1983 is based on two wing bases. Nevertheless, it differs from Paraostrava in its $\mathrm{CuA}$ with three branches. Larryia osterbergi KukalováPeck \& Richardson, 1983 has the base of RP in a very distal position, far from that of MA, and has MA distally forked and $\mathrm{CuA}$ divided into three main branches, unlike Paraostrava. Mazonopterum wolfforum Kukalová-Peck \& Richardson, 1983 has no long sigmoidal secondary veins in the area between RA and RP, a long distance between bases of MA and of RP, even if that of RP is in a distal position, unlike Paraostrava. Mazonopterum shares with Paraostrava the simple MA and CuA.

Parathesoneura Sinitshenkova, 1977 (with two species $P$. carpenteri and $P$. anfractuosa, in Sharov \& Sinitshenkova, 1977: 52-54) shares with Paraostrava the almost simple MA and $\mathrm{CuA}$, and the presence of long sigmoidal veinlets in the area between RA and RP. However, they have a very long basal part of RP, between its base and first branch, and the base of MA distal to that of RP, unlike Paraostrava.

Note that there is a strong similarity between Parathesoneura and Archaemegaptilus Meunier, 1908 (type genus of the Archaemegaptilidae Handlirsch, 1919), viz. they share a very long basal part to RP, the same organization of MA, MP and CuA, and the presence of long sigmoidal veinlets in RA - RP area (Kukalová, 1969: Fig. 46). There are very few visible differences between the two taxa, in the number of branches of MP. Sinitshenkova (2002: 117) included the Archaemegaptilidae in the Eugereonoidea Handlirsch, 1906 (sensu Sinitshenkova, 2002). She characterized this last super- 
family by (1) their wings long and narrow, and (2) the "archedictyon" lost. The first character is not obvious in the type specimen of Archaemegaptilus kiefferi Meunier, 1908 because the basal half of its wing is not preserved. The second character is convergently present in the Homoiopteroidea. Thus, a phylogenetic revision of the position of the Archaemegaptilidae would be necessary to clarify this situation.

Scepasma Handlirsch, 1911 (two species, S. gigas Handlirsch, 1911 and S. mediomatricorum Brauckmann \& Becker, 1992) has a simple $\mathrm{CuA}$, but MA with one strong fork, unlike Paraostrava (Kukalová-Peck \& Richardson, 1983; Brauckmann \& Becker, 1992).

Boltopruvostia Strand, 1929 is based on the type species B. robusta (Pruvost, 1919), a poorly known taxon, based on two wing bases attached to the thorax. Another species, B. nigra (Kukalová, 1960) is based on a nearly complete fore wing, originally attributed to the genus Ostrava Kukalová, 1960, later synonymized with Boltopruvostia (Kukalová, 1969). In Boltopruvostia nigra, the fork of the radius is distinctly basal to that of the median vein, unlike its distinctly distal position in $B$. robusta (Kukalová, 1960: Figs 1-2). This difference is not sufficient for a generic separation of Boltopruvostia because Brauckmann (1991b) demonstrated on rich material that a rather important variability occurs in the relative positions of these vein bases in Homoioptera vorhallensis. There are no visible differences between Boltopruvostia robusta and Paraostrava in their comparable preserved parts of wing venation, viz. bases of RP, fork of $\mathrm{M}$, and bases of $\mathrm{CuA}$ and $\mathrm{CuP}$ (Pruvost, 1919: Pls 1-2). But nothing is known concerning the distal two-thirds of the wing venation of Boltopruvostia robusta. Thus, it is not possible to compare it accurately between Paraostrava and Boltopruvostia nigra.

Furthermore, Paraostrava and Boltopruvostia nigra differ in the relative widths of the area between RA and RP: about twice broader than that between RP and MA in Paraostrava, instead of being of the same width in Boltopruvostia nigra. This character is sufficient for a generic separation between these two taxa. But it is unknown in Boltopruvostia robusta.

As it is not possible to accurately attribute Paraostrava or Boltopruvostia nigra to Boltopruvostia, we choose better to restore the combination of genus Ostrava Kukalová, 1960 with Ostrava nigra Kukalová, 1960, to erect a new genus and species for Paraostrava stanislavi, and to consider Boltopruvostia robusta as Palaeodictyoptera: Homoiopteridae of uncertain position.

\section{CONCLUSIONS}

(1) The genus Ostrava Kukalová, 1960: 241 (type species Ostrava nigra Kukalová, 1960 by monotypy) is restituted.

(2) Boltopruvostia Strand, 1929 (type species Boltopruvostia robusta (Pruvost, 1919) by monotypy) is considered as Palaeodictyoptera: Homoiopteridae with uncertain position according to the poor state of preservation.
Boltopruvostia Strand, 1929: 20 as nomen novum for Boltonia Pruvost, 1919: 284, non Koenig, 1820.

(3) Paraostrava gen. n. is established for Paraostrava stanislavi sp. n. (type species).

ACKNOWLEDGEMENTS. We especially thank to S. Opluštil (Charles University) who saved this specimen and kindly helped on geology and stratigraphy. We also thank to M. Libertín (National Museum Prague) for new data relating to palaeobotany of this site according to the running project: IAA3013306. Finally we are grateful to J. Kukalová-Peck, X. Martínez-Delclòs, R.J. Wootton, P. Stys and an anonymous reviewer for their useful comments to the manuscript. The research was supported by a grant of the Ministry of Schools J13/98-113100004 and COLPARSYST program of the Muséum National d'Histoire Naturelle in Paris.

\section{REFERENCES}

BECHLY G. 1996: Morphologische Untersuchungen am Flügelgeäder der rezenten Libellen und deren Stammgruppenvertreter (Insecta; Pterygota; Odonata) unter besonderer Berücksichtigung der Phylogenetischen Systematik und des Grundplanes der *Odonata. Petalura (Spec. Vol.) 2: 1-402.

BECHLY G. 1997: New fossil odonates from the Upper Triassic of Italy, with a redescription of Italophlebia gervasuttii, and a reclassification of Triassic dragonflies (Insecta: Odonata). Riv. Mus. Civ. Sci. Nat. "E. Caffi” 19: 31-70.

BrauckManN C. 1991a: Arachniden und Insekten aus dem Namurium von Hagen-Vorhalle (Ober-Karbon, WestDeutschland). Veröffentlichungen aus dem Fuhlrott-Museum, Wuppertal, $275 \mathrm{pp}$.

Brauckmann C. 1991b: Morphologie und Variabilität von Homoioptera vorhallensis (Insecta, Palaeodictyoptera, OberKarbon). Geol. Palaeont. 25: 193-213.

Brauckmann C. \& Becker R. 1992: Ein neues Riesen-Insekt aus dem Ober-Karbon des Saarlandes (Palaeodictyoptera: Homoiopteridae). Geol. Palaeont. 26: 135-141.

BrauckManN C. \& Herd K.J. 2002: Insekten-Funde aus dem Westfalium D (Ober-Karbon) des Piesberges bei Osnabrück (Deutschland). Teil 1: Palaeoptera. Osnabrücker Naturwiss. Mitt. 28: 27-69.

BraucKMANN C. \& Koch L. 1982: Neue Insekten aus den Vorhalle-Schichten (Ober Namurium B) von Hagen-Vorhalle. Dortmunder Beitr. Landeskde Naturwiss. Mitt. 16: 15-26.

Carpenter F.M. 1992: Superclass Hexapoda. In Moore R.C. \& Kaesler R.L. (eds): Treatise on Invertebrate Paleontology. Arthropoda 4, 3/4. Geological Society of America and the University of Kansas, Boulder, Colorado, 655 pp.

GRIMALDI D. 2001: Insect evolutionary history from Handlirsch to Hennig, and beyond. J. Paleont. 75: 1152-1160.

Handlirsch A. 1904: Les insectes houillers de la Belgique. Mém. Mus. Roy. Hist. Nat. Belg. 3: 1-20.

HaNDLIRSCH A. 1906a (1906-1908): Die fossilen Insekten und die Phylogenie der rezenten Formen. Ein Handbuch für Paläontologen und Zoologen. 1430 pp. (Engelman V.W. publ., Leipzig) [published in parts between 1906 and 1908 as follows: pp. i-vi, 1-160, pls 1-9 (May 1906); pp. 161-320, pls 10-18 (June 1906); pp. 321-480, pls 19-27 (August 1906); pp. 481-640, pls 28-36 (October 1906); pp. 641-800, pls 37-45 (February 1907); pp. 801-960, pls 46-51 (June 1907); pp. 961-1120 (November 1907); pp. 1121-1280 (January 1908); pp. vii-ix, 1281-1430 (July 1908). Dated from publication information given on $\mathrm{p}$. ix.]

Handlirsch A. 1906b: Revision of American Paleozoic insects. Proc. U.S. Nat. Mus. Wash. 29: 661-820. 
Kukalová J. 1959: New Paleodictyoptera of the Carboniferous and Permian of Czechoslovakia. Sbor. Ústřr. Úst. Geol. 25[1960]: 239-251.

KuKalové J. 1969: Revisional study of the order Palaeodictyoptera in the Upper Carboniferous shales of Commentry, France. Part 2. Psyche 76: 439-486.

KuKalovÁ-PecK J. 1972: Unusual structure in the Paleozoic insect orders Megasecoptera and Palaeodictyoptera with description of a new family. Psyche 79: 243-268.

Kukalová-Peck J. 1991: Fossil history and evolution of hexapod structures. In Naumann I.D., Crane P.B., Lawrence J.F., Nielsen E.S., Spradbery J.P., Taylor R.W., Whitten M.J. \& Littlejohn M.J. (eds): The Insects of Australia. A Textbook for a Students and Research Workers. 2nd ed. Vol. 1. Melbourne University Press, Melbourne, pp. 141-179.

Kukalová-Peck J. \& Richardson E.S.JR. 1983: New Homoiopteridae (Insecta: Paleodictyoptera) with wing articulation from Upper Carboniferous strata of Mazon Creek, Illinois. Can. J. Zool. 61: 1670-1687.

Novokshonov V.G. 1993: New insects (Insecta) from the Lower Permian of Chekarda (Central Urals). Paleont. J. 27(1A): 172-178.

Pruvost P. 1919: Introduction à l'étude du terrain houiller du Nord et du Pas-de-Calais. La faune continentale du terrain houiller du Nord de la France. Mémoires pour servir à l'Explication de la Carte Géologique de la France 1919: 1-584.

RIEK E.F. 1976: Neosecoptera, a new insect suborder based on specimen discovered in the Late Carboniferous of Tasmania. Alcheringa 1: 227-234.

RoHDENDORF B.B. 1961: Podklass Pterygota. [Subclass Pterygota.] In Rohdendorf B.B., Becker-Migdisova E.E.,
Martynova O.M. \& Sharov A.: Paleozojskie nasekomye kuznetskogo bassejna [Palaeozoic insects of the Kuznetsk basin]. Trud. Paleont. Inst. Akad. Nauk SSSR 85: 69-88.

Sharov A.G. \& Sinitshenkova N.D. 1977: Novye Paleodictyoptera s territory SSSR. [New Palaeodictyoptera from the USSR.] Paleont. Zh. 1977 (1): 48-63. [English translation in Paleont. J. 11 (1): 48-63.]

Sinitshenkova N.D. 2002: Chapter 2.2.1.2.3. Superorder Dictyoneuridea Handlirsch, 1906 (= Palaeodictyopteroidea). In Rasnitsyn A.P. \& Quicke D.L.J. (eds): History of Insects. Kluwer Academic Publishers, Dordrecht, Boston, London, pp. $115-124$.

Spudil J. 1999: Group of seams of the Šverma Mine at Žaclér (Intra-Sudetic Basin). Acta Univ. Carol. (Geol.) 43: 589-598.

Tásler R., Čadková Z., Dvořák J., Fediuk F., Chaloupský J., Jetel J., Kaiserová-Kalibová M., Prouza V., SchovánKováHrdličKová D., StŘEda J., STŘída M. \& Š́etlík J. 1979: Geologie české části vnitrosudetské pánve. [Geology of the Bohemian Part of the Intra-Sudetic Basin.] Československá akademie věd, Praha, 292 pp. (in Czech).

Wootton R.J. \& Kukalová-Peck J. 2000: Flight adaptations in Palaeozoic Palaeoptera (Insecta). Biol. Rev. 75: 129-167.

\section{APPENDIX}

List of coding characters used to separate the genera of Homoiopteroidea (Homoiopteridae + Heolidae), see Table 1:

1. "Archedictyon" (reticulate venation after Wootton \& Kukalová-Peck 2000): present [0]; absent [1]; uncertain or very strongly reduced [2].

2. ScP: ending in basal position, close to mid wing [0]; ending well distal of mid wing, closer to wing apex [1].

TABLE 1. Characters matrix used to separate the genera of Homoiopteroidea.

\begin{tabular}{|c|c|c|c|c|c|c|c|c|c|c|c|}
\hline Homoiopteroidea (Homoiopteridae + Heolidae) sensu Sinitshenkova (2002) & Wing & 1 & 2 & 3 & 4 & 5 & 6 & 7 & 8 & 9 & 10 \\
\hline Homoioptera woodwardi Brongniart, 1893 & yes & 2 & 1 & 0 & 1 & 1 & 0 & 0 & 0 & 0 & 1 \\
\hline Homoioptera gigantea Agnus, 1902 & yes & 2 & 1 & 0 & 0 & 1 & 0 & 0 & 1 & 0 & 1 \\
\hline Homoioptera latipennis (Handlirsch, 1904) & yes & 1 & 1 & 0 & 0 & 1 & 0 & 0 & 1 & $?$ & 0 \\
\hline Homoioptera vorhallensis Brackmann \& Koch, 1982 & yes & 0 & 1 & 0 & 0 & 1 & 0 & 0 & 1 & 0 & 0 \\
\hline Homoioptera kortumi Brauckmann \& Herd, 2002 & yes & 0 & 1 & 0 & 0 & 1 & 1 & 0 & $0 / 1$ & 0 & 0 \\
\hline Adolarryia bairdi Kukalová-Peck \& Richardson, 1983 & yes & $?$ & 1 & $?$ & $?$ & 1 & $?$ & 0 & 1 & 1 & 0 \\
\hline Ametretus laevis Handlirsch, 1911 & yes & $?$ & $?$ & $?$ & $?$ & $?$ & $?$ & 0 & $?$ & 0 & ? \\
\hline Amousus mazonus Handlirsch, 1911 & yes & 0 & $?$ & $?$ & ? & $?$ & $?$ & 0 & $?$ & $?$ & 1 \\
\hline Boltopruvostia robusta (Pruvost, 1919) & yes & 0 & $?$ & $?$ & $?$ & $?$ & $?$ & $?$ & $?$ & 0 & 1 \\
\hline Larryia osterbergi Kukalová-Peck \& Richardson, 1983 & yes & 2 & 0 & 0 & 0 & 0 & 0 & 0 & 1 & 0 & 0 \\
\hline Mammia alutacea Handlirsch, 1906 & yes & 0 & $?$ & $?$ & ? & $?$ & $?$ & $?$ & ? & 0 & 1 \\
\hline Mazonopterum wolfforum Kukalová-Peck \& Richardson, 1983 & yes & 0 & 1 & 0 & 0 & 1 & 0 & 1 & 1 & 1 & 0 \\
\hline Mazothairos enormis Kukalová-Peck \& Richardson, 1983 & no & $?$ & $?$ & $?$ & $?$ & ? & $?$ & $?$ & $?$ & ? & ? \\
\hline Ostrava nigra Kukalová, 1960 & yes & 2 & 1 & 0 & 0 & 1 & 0 & 1 & 1 & 0 & 0 \\
\hline Parathesoneura carpenteri Sinitshenkova in Sharov \& Sinitshenkova, 1977 & yes & 2 & 1 & 1 & 0 & 1 & 1 & 1 & 0 & 0 & 0 \\
\hline Parathesoneura anfractuosa Sinitshenkova in Sharov \& Sinitshenkova, 1977 & yes & 2 & $?$ & 1 & 0 & $?$ & 1 & 1 & 0 & 0 & 0 \\
\hline Scepasma gigas Handlirsch, 1911 & yes & 0 & 1 & 0 & 0 & 0 & 0 & 1 & 0 & 0 & 0 \\
\hline Scepasma mediomatricorum Brauckmann \& Becker, 1992 & yes & 2 & 1 & 0 & 0 & 0 & $?$ & 1 & 0 & 0 & 0 \\
\hline Thesoneura americana Carpenter, 1944 & yes & 2 & 1 & 0 & 0 & 1 & 0 & 0 & 0 & 0 & 0 \\
\hline Turneropterum turneri Kukalová-Peck \& Richardson, 1983 & yes & 0 & $?$ & $?$ & $?$ & $?$ & $?$ & 0 & $?$ & 1 & 0 \\
\hline Paraostrava stanislavi gen. $\mathrm{n}, \mathrm{sp} . \mathrm{n}$. & yes & 2 & 1 & 1 & 1 & 1 & 0 & 0 & 1 & $?$ & 0 \\
\hline Heolus providentiae Handlirsch, 1919 & yes & 1 & 1 & 0 & 1 & 1 & 0 & 0 & 0 & ? & 1 \\
\hline
\end{tabular}


3. Secondary veins in area between RA and RP: long sigmoidal veinlets absent or very few [0]; long sigmoidal veinlets numerous [1].

4. Area between RA and RP: nearly of same width as area between RP and MA [0]; distinctly broader than area between $\mathrm{RP}$ and MA [1].

5. MA: with at least two long branches [0]; simple or with only short apical weak branches [1].

6. Basal part of RP, basal of first branch of RP: relatively short, shorter than distal part of RP [0]; very long, at least as long as distal part of RP [1].
7. CuA: with at least two long branches [0]; simple or with only short apical weak branches [1].

8. MP: with few branches, less than four [0]; with numerous branches, four or more [1].

9. Basal part of $\mathrm{CuA}$ : without a strong anterior curve [0]; with a strong anterior curve [1].

10. Basal part of MA: without a strong anterior curve [0]; with a strong anterior curve [1].

Received November 11, 2003; revised July 2, 2004; accepted August 30, 2004 